Research Paper

\title{
Breast cancer stem cell markers CD44 and ALDH1A1 in serum: distribution and prognostic value in patients with primary breast cancer
}

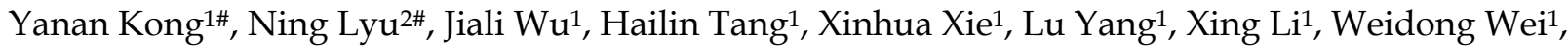 \\ Xiaoming Xie $\mathrm{Xi}^{\bowtie}$ \\ 1. Department of Breast Oncology, Sun Yat-sen University Cancer Center, Guangzhou, China. \\ 2. State Key Laboratory of Oncology in South China; Department of Minimally Invasive Intervention, Sun Yat-sen University Cancer Center, Guangzhou, \\ China. \\ \# These authors contributed equally to this article.
}

$\square$ Corresponding author: Xiaoming Xie, M.D. \& Ph.D., Department of Breast Oncology, Sun Yat-sen University Cancer Center; State Key Laboratory of Oncology in South China; Collaborative Innovation Center for Cancer Medicine, 651 Dongfeng Road East, Guangzhou, Guangdong 510060, P. R. China. Tel: 86-20-87343806; Fax: 86-20-87343806; E-mail address: xiexm@sysucc.org.cn.

( ) Ivyspring International Publisher. This is an open access article distributed under the terms of the Creative Commons Attribution (CC BY-NC) license (https://creativecommons.org/licenses/by-nc/4.0/). See http://ivyspring.com/terms for full terms and conditions.

Received: 2018.06.21; Accepted: 2018.08.09; Published: 2018.09.08

\begin{abstract}
Background: CD44 and ALDHI have been recognized as the most widely used markers to identify breast cancer stem cells (BCSCs). However, limited to tissue sample and rare population, BCSCs have always been not easily detected. We aimed to measure CD44 and ALDHIAI (major contributor to ALDHI activity) levels in serum and explore the prognostic value in primary breast cancer patients.

Methods: This study included 140 primary breast cancer patients with stage I-III. Serum samples were collected before surgery and stored at -80 degrees. CD44 and ALDHIAl were measured by chemiluminescent assay.

Results: High serum CD44 levels $(\geq 417.4 \mathrm{ng} / \mathrm{mL})$ were correlated with postmenopausal status $(P=$ $0.006)$, estrogen receptor negativity $(P=0.025)$, progesterone receptor negativity $(P=0.002)$ and adjuvant chemotherapy $(P=0.003)$. The mean serum CD44 levels of luminal group $(406.4 \pm 68.3 \mathrm{ng} / \mathrm{mL})$ were significantly lower than triple negative group $(506.8 \pm 175.5 \mathrm{ng} / \mathrm{mL})(P<0.001)$. There was no correlation between serum ALDHIAI levels and molecular subtypes. Multivariate analysis revealed that high serum CD44 level ( $\geq 417.4 \mathrm{ng} / \mathrm{mL})$, was an independent factor for PFS $(P=0.019)$ and OS $(P=0.008)$. However, serum ALDHIA1 has no impact on either PFS $(P=0.613)$ or OS $(P=0.441)$.

Conclusion: Serum CD44 was an independent prognostic indicator in primary breast cancer. However, serum ALDHIAl has no impact on survivals and might not be an appropriate candidate to predict prognosis for breast cancer.
\end{abstract}

Key words: CD44, ALDH1A1, breast cancer, stem cells, prognosis

\section{Introduction}

Breast cancer is the second most common cause of cancer-related death in women worldwide, and the incidence is still increasing rapidly, especially in moderate and low-income countries [1]. Although comprehensive therapies including surgery, chemotherapy, radiotherapy, endocrine and targeted therapy, even the novel immunotherapy have been applied to breast cancer, recurrence and metastasis still occur years after therapies in many patients, leading to a high mortality [2]. Recent studies have revealed that there exists a small distinct population of cancer stem cells in breast tumors, which could initiate a tumor, mediate progression and resist to chemotherapy and radiation, contributing to treatment failure and disease relapse [3]. Hence, identifying and monitoring breast cancer stem cells 
has a significant meaning to predict therapy resistance and prognosis, which may provide a novel target to cure breast cancer $[4,5]$.

However, breast cancer stem cells (BCSCs) only account for about $2 \%$ of breast cancer cells and is hard to be isolated from human tumor tissue. Since Al-Hajj et al found that a subgroup of breast cancer cells expressing $\mathrm{CD} 44^{+} / \mathrm{CD} 24^{-}$represented distinct characteristics of BCSCs, a variety of researches have been searching for surface markers to identify BCSCs [6]. Now the most used BCSC markers including $\mathrm{CD}_{4}{ }^{+}, \mathrm{CD}^{2} 4^{-}$, aldehyde dehydrogenase (ALDH) ${ }^{+}$, $\mathrm{EpCAM}^{+}, \mathrm{LGR}^{+}[5,7,8]$, and identification of these markers in tissue clinically were demonstrated meaningful in predicting tumor response, metastasis and survival. Nevertheless, the only approach to acquire tissue samples is biopsy or surgery that is invasive, moreover, samples could not be taken repeatedly from the breast tumor.

Recent years, circulating tumor cells (CTCs), which detached from the primary tumor and intravasated into the blood, became the research hotspot. As a method of noninvasive and repeatable liquid biopsy, CTCs can be detected in the peripheral blood and proved to be a prognostic factor for overall survival (OS) in patients with metastatic breast cancer $[9,10]$. Data implicated that CTCs $>5 / 7.5 \mathrm{ml}$ in peripheral blood may correlated with worse survival [11]. Therefore, researchers tried to search cancer stem cells from CTCs in peripheral blood by using series of BCSCs markers including EPCAM, CD44, CD24, ALDH1, CD133, LGR5 and PIWIL2, and explored whether it was possible to use circulating BCSCs to monitor prognosis and response to therapy [8, 12-18]. However, the results were not satisfying, because there were so less CTCs in circulation, not saying the BCSCs. Considering that the most widely used biomarkers CEA and CA153, we supposed that whether BCSCs markers can also be detected in serum. In this study, we selected two BCSCs markers CD44 and ALDH1A1 (major contributor to ALDH1 activity), to explore the correlation between their serum levels and clinicopathological parameters, and the prognostic value of serum CD44 and ALDH1 in patients with breast cancer.

\section{Patients and Methods}

This retrospective study was approved by the Ethical Review Committee of Sun Yat-sen University Cancer Center (No. GYX2015-016) and was conducted in accordance with the principles of the Declaration of Helsinki. Informed consents were obtained from all patients before the commencement of the study. From Dec 2001 to Dec 2004, 140 primary breast cancer patients with stage I-III undergoing mastectomy or breast conserving surgery in the center were enrolled in this study. The mean age was 48.9 years and the standard deviation was 11.5 years. Breast cancer was diagnosed by pathology using surgical tumor tissue. Pathological stage of tumor was classified based on The American Joint Committee on Cancer (AJCC) seventh edition staging manual. Patients with any other primary malignant tumors or with loco-regional recurrence and distant metastasis at the time of diagnosis were excluded from this study.

\section{Serum CD44 and ALDHIAl assays}

Serum samples were obtained from the department of breast oncology in Sun Yat-sen University Cancer Center, which were collected at the time of cancer diagnosis and stored at $-80^{\circ} \mathrm{C}$. Both the human CD44and ALDH1A1 were quantitative detected using an enzyme-linked immunosorbent assay kit according to the manufacturer's operating instructions (Abnova Corporation, Taipei City, Taiwan), and all the measurements were performed in triplicate. The CD44std kit detect all circulating CD44 isoforms that include the standard protein sequence and the protocol was as follows: First, the antihuman CD44 antibody was precoated into a wells of 96-well microtiter plates. The serum sample was diluted to a 1:30 concentration in sample diluent and was added to the wells. Then, a horseradish peroxidaseconjugated monoclonal antibody against CD44 was added to the wells. The CD44 molecules present in the serum bound to the antibodies. Then, the wells were incubated at room temperature $\left(18\right.$ to $\left.25^{\circ} \mathrm{C}\right)$ for 3 hours. After incubation, unbound enzyme-conjugated antibodies were removed by washing three times with wash buffer, and substrate solution $(100 \mu \mathrm{L})$ was added to wells. The coloring reaction was terminated by the addition of stop acid, and absorbance was measured at $450 \mathrm{~nm}$ by a 2-site chemiluminescence's sandwich immunoassay (ADVIA Centaur System, Siemens Diagnostics). To determine CD44 concentrations, a standard curve was constructed using serially diluted CD44 antigens and then compared them with the experimental serum samples.

ALDH1A1 was measured as follows: First, serum sample, the standard and blank were added to the wells and incubated for 2 hours at $37^{\circ} \mathrm{C}$. Then, solution A $(100 \mu \mathrm{L})$ was added, incubated at $37{ }^{\circ} \mathrm{C}$ for 1 hour and washed by buffer for 3 times. Solution B $(100 \mu \mathrm{L})$ was added and repeated the procedures as the solution A. Then substrate solution $(90 \mu \mathrm{L})$ was added to wells and were incubated at $37{ }^{\circ} \mathrm{C}$ for $15-30$ minutes. The coloring reaction was terminated by the addition of $50 \mu \mathrm{L}$ stop acid, and the absorbance was measured at $450 \mathrm{~nm}$ by a 2-site chemiluminescence's 
sandwich immunoassay (ADVIA Centaur System, Siemens Diagnostics). A standard curve was also constructed using serially diluted ALDH1A1 antigens and then compared them with the experimental serum samples.

\section{Follow-up and Assessments}

All patients were followed up with routine examination, which including physical examination, radiological examination and laboratory tests and were obtained within 2 weeks before the commencement of treatment and then were carried out during follow-up (every 3 months for the first 2 years, every 6 months for the next 3 years and one year after 5 years). Radiologic examination included ultrasonography of chest wall on affected side, contralateral breast, bilateral axillary and supraclavicular lymph nodes and liver, mammography, chest radiography, bone scanning and further image modalities such as diagnostic computed tomography and/or magnetic resonance imaging if indicated. Laboratory tests included test of serum CEA and CA153. First appearance of a new tumor recurrence in locoregional area and distant organs or in combination of these was defined as disease progression.

Progression free survival (PFS) was calculated as time from the commencement of treatment to disease progression or death, no matter which occurred first. Patients who were alive and disease free were censored at the date of last follow-up visit. OS was defined as the time interval between the first treatment and death for any cause, and patients who were alive were censored at date of last follow-up visit. Patients were followed up until Feb 20, 2018.

\section{Statistical analysis}

Chi-Square test or Fisher's exact test was used to evaluate the correlation between serum CD44 and ALDH1A1 and clinicopathological characteristics in all categorical tables. Survival curves were generated by using Kaplan-Meier method. We used Cox regression models to evaluate the impact of serum CD44 and ALDH1A1 and clinicopathological characteristics on PFS and OS. Univariate and multivariate analysis were both used in proportional hazard, which was described by hazard ratio (HR) with 95\% confidence interval (CI). Statistically significant factors in the univariate analyses were analyzed in multivariate analysis to evaluate the association between time-dependent outcomes and survival. Both serum CD44 and ALDH1A1 were bifurcated at the median levels. All the data were analyzed using SPSS v20 (SPSS, Inc., Chicago IL), and all $\mathrm{P}$ values $<0.05$ were considered to suggest significant difference. All data in this study have been recorded at the Sun Yat-sen University Cancer Center (number: RDDA2018000764).

\section{Results}

\section{Relationship between serum CD44 and ALDH1A1 levels and clinicopathological characteristics}

In a total 140 patients, the median serum CD44 levels was $417.4 \mathrm{ng} / \mathrm{mL}$, ranged from $220.8 \mathrm{ng} / \mathrm{mL}$ to $1216.7 \mathrm{ng} / \mathrm{mL}$. We observed that high serum CD44 levels $(\geq 417.4 \mathrm{ng} / \mathrm{mL})$ were correlated with postmenopausal status $(P=0.006)$, estrogen receptor (ER) negative $(P=0.025)$, progesterone receptor $(\mathrm{PR})$ negative $(P=0.002)$ and adjuvant chemotherapy $(P=$ 0.003). The median serum ALDH1A1 levels were $0.778 \mathrm{ng} / \mathrm{mL}$, ranged between 0 and $8.085 \mathrm{ng} / \mathrm{mL}$. Patients with high ALDH1A1 levels $(\geq 0.776 \mathrm{ng} / \mathrm{mL})$ had a higher frequency of positive HER2 status than those who with low ALDH1A1 levels (32.9\% vs. $17.1 \%, P=0.032$ ). There was also significant difference in serum ALDH1A1 levels according to PR status $(P=$ 0.017) (Table 1).

\section{Impact of serum CD44 and ALDHIAl on prognosis in primary breast cancer}

With a median follow-up of 139.3 months, total recurrence rate was $38.6 \%$ (54 in 140 patients). 4 patients $(2.9 \%)$ had locoregional recurrence, 43 patients $(30.7 \%)$ had distant metastasis and 3 patients (2.1\%) had locoregional and distant recurrence synchronously. Liver was the most popular metastatic organ $(n=22)$ followed by lung $(n=14)$, bone $(n=12)$, supraclavicular lymph node $(\mathrm{n}=8)$ and brain $(\mathrm{n}=6)$. 54 patients died of recurrence, and 4 patients died free of breast cancer by the end date of Fer 20, 2018.

We separately divided all patients into two groups according to the median levels of CD44 or ALDH1A1. Patients in the high serum CD44 group ( $\geq$ $417.4 \mathrm{ng} / \mathrm{mL})$ had a significantly shorter OS $(P=$ $0.0095)$ (Fig. 1A) and PFS $(P=0.0176)$ than those in the low CD44 group (Fig. 1B). However, there was no significant difference in either OS $(P=0.3488)$ or PFS $(P=0.4425)$ between patients with high serum ALDH1A1 levels ( $\geq 0.776 \mathrm{ng} / \mathrm{mL}$ ) and low (Fig. 2). To further find out a narrow range that could identify patients with poor prognosis, four subgroups were classified according to quartiles. It showed that patients with serum CD44 level more than the third quartile $(\geq 477.9 \mathrm{ng} / \mathrm{mL}$ ) had the worse OS (CD44 level < $368.3 \mathrm{ng} / \mathrm{mL}: P=0.002 ; \mathrm{CD} 44$ level between $368.3 \mathrm{ng} / \mathrm{mL}$ and $417.4 \mathrm{ng} / \mathrm{mL}: P=0.002$; and CD44 level between $417.4 \mathrm{ng} / \mathrm{mL}$ and $477.9 \mathrm{ng} / \mathrm{mL}: P=$ $0.015)$ and PFS (CD44 level < $368.3 \mathrm{ng} / \mathrm{mL}: P=0.016$; 
CD44 level between $368.3 \mathrm{ng} / \mathrm{mL}$ and $417.4 \mathrm{ng} / \mathrm{mL}: P$ $=0.002$; and CD44 level between $417.4 \mathrm{ng} / \mathrm{mL}$ and $477.9 \mathrm{ng} / \mathrm{mL}: P=0.033)$ than other three subgroups. However, there was no difference of OS and PFS among other three subgroups $(P>0.05)$. A univariate analysis of prognostic factors showed that large tumor size, positive lymph nodes, negative ER and PR status and higher serum CD44 levels had significantly shorter OS. Serum ALDH1A1 levels did not appear to have any impact on OS $(P=0.441)$. In multivariate COX analysis, larger tumor size $(>5 \mathrm{~cm})(\mathrm{HR}, 3.563$; 95\% CI, 1.376-9.226; $P=0.009), 1$ to 3 positive lymph nodes (HR, 2.305; 95\% CI, 1.136-4.678; $P=0.021$ ), more than 4 positive lymph nodes (HR, 5.436; 95\% CI, 2.854-11.433; $P<0.001)$ and higher serum CD44 levels $(\geq 477.9 \mathrm{ng} / \mathrm{mL})(\mathrm{HR}, 2.874 ; 95 \% \mathrm{CI}, 1.286-6.423 ; P=$ 0.01 ) were independent indicators of OS (Table 2). Similarly, these variables were also independent indicators of PFS in the COX regression model (Table $3)$.

Table 1. Association between serum CD44 and serum ALDHIAl and clinicopathological characteristics in breast cancer patients.

\begin{tabular}{|c|c|c|c|c|c|c|c|c|}
\hline \multirow[b]{2}{*}{ Characteristics } & \multirow[b]{2}{*}{$\mathrm{N}$} & \multirow[b]{2}{*}{$\%$} & \multicolumn{3}{|c|}{$\begin{array}{l}\text { Serum CD44 levels } \\
\text { (ng/ mL) }\end{array}$} & \multicolumn{3}{|c|}{$\begin{array}{l}\text { Serum ALDH1A1 levels } \\
\text { (ng/ mL) }\end{array}$} \\
\hline & & & $\begin{array}{l}< \\
417.4\end{array}$ & $\begin{array}{l}\geq \\
417.4\end{array}$ & $\begin{array}{l}P \\
\text { value }\end{array}$ & $<0.778$ & $\geq 0.778$ & P value \\
\hline Total & 140 & 100 & 70 & 70 & - & 70 & 70 & - \\
\hline \multicolumn{9}{|l|}{ Age (years) } \\
\hline$\leq 35$ & 15 & 10.7 & 8 & 7 & 0.785 & 10 & 5 & 0.172 \\
\hline$>35$ & 125 & 89.3 & 62 & 63 & & 60 & 65 & \\
\hline \multicolumn{9}{|l|}{ Menopausal status } \\
\hline Premenopausal & 80 & 57.1 & 48 & 32 & 0.006 & 42 & 38 & 0.495 \\
\hline Postmenopausal & 60 & 42.9 & 22 & 38 & & 28 & 32 & \\
\hline \multicolumn{9}{|l|}{ Stage } \\
\hline I & 30 & 21.4 & 14 & 16 & 0.882 & 15 & 15 & 1.000 \\
\hline II & 76 & 54.3 & 38 & 38 & & 38 & 38 & \\
\hline III & 34 & 24.3 & 18 & 16 & & 16 & 18 & \\
\hline \multicolumn{9}{|l|}{ Tumor size $(\mathrm{cm})$} \\
\hline$\leq 2$ & 48 & 34.3 & 24 & 24 & 0.546 & 25 & 23 & 0.762 \\
\hline 2 to 5 & 76 & 54.3 & 36 & 40 & & 36 & 40 & \\
\hline$>5$ & 16 & 11.4 & 10 & 6 & & 9 & 7 & \\
\hline \multicolumn{9}{|l|}{$\begin{array}{l}\text { Lymph nodes status } \\
(+)\end{array}$} \\
\hline 0 & 67 & 47.9 & 35 & 32 & 0.861 & 37 & 30 & 0.489 \\
\hline $1-3$ & 45 & 32.1 & 22 & 23 & & 20 & 25 & \\
\hline$\geq 4$ & 28 & 20 & 13 & 15 & & 13 & 15 & \\
\hline \multicolumn{9}{|l|}{ ER status } \\
\hline Negative & 57 & 40.7 & 22 & 35 & 0.025 & 24 & 33 & 0.122 \\
\hline Positive & 83 & 59.3 & 48 & 35 & & 46 & 37 & \\
\hline \multicolumn{9}{|l|}{ PR status } \\
\hline Negative & 62 & 44.3 & 22 & 40 & 0.002 & 24 & 38 & 0.017 \\
\hline Positive & 78 & 55.7 & 48 & 30 & & 46 & 32 & \\
\hline \multicolumn{9}{|l|}{$\begin{array}{l}\text { HER2 }\left(\text { IHC/FISH) }{ }^{\dagger}\right. \\
\text { status }\end{array}$} \\
\hline Negative & 105 & 75 & 52 & 53 & 0.845 & 58 & 47 & 0.032 \\
\hline Positive & 35 & 25 & 18 & 17 & & 12 & 23 & \\
\hline \multicolumn{9}{|l|}{ Surgery } \\
\hline $\begin{array}{l}\text { Breast conserving } \\
\text { surgery }\end{array}$ & 5 & 3.6 & 2 & 3 & 0.649 & 4 & 1 & 0.172 \\
\hline Mastectomy & 135 & 96.4 & 68 & 67 & & 66 & 69 & \\
\hline \multicolumn{9}{|l|}{$\begin{array}{l}\text { Adjuvant systematic } \\
\text { treatment }\end{array}$} \\
\hline Chemotherapy & 125 & 89.3 & 68 & 57 & 0.003 & 61 & 64 & 0.412 \\
\hline Endocrine therapy & 82 & 58.6 & 44 & 38 & 0.303 & 43 & 39 & 0.493 \\
\hline
\end{tabular}

\begin{tabular}{|c|c|c|c|c|c|c|c|c|}
\hline \multirow[b]{2}{*}{ Characteristics } & \multirow[b]{2}{*}{$\mathrm{N}$} & \multirow[b]{2}{*}{$\%$} & \multicolumn{3}{|c|}{$\begin{array}{l}\text { Serum CD44 levels } \\
\text { (ng/ mL) }\end{array}$} & \multicolumn{3}{|c|}{$\begin{array}{l}\text { Serum ALDH1A1 levels } \\
\text { (ng/ mL) }\end{array}$} \\
\hline & & & $\begin{array}{l}< \\
417.4\end{array}$ & $\begin{array}{l}\geq \\
417.4\end{array}$ & $\begin{array}{l}\mathrm{P} \\
\text { value }\end{array}$ & $<0.778$ & $\geq 0.778$ & $\mathrm{P}$ value \\
\hline Radiotherapy & 22 & 15.7 & 12 & 10 & 0.642 & 12 & 10 & 0.642 \\
\hline Targeted therapy & 2 & 1.4 & 1 & 1 & 1.000 & 2 & 0 & 0.154 \\
\hline
\end{tabular}

\section{Subgroup analysis of Serum CD44 and ALDHIA1 levels and molecular subtypes}

The mean serum CD44 levels of breast cancer patients with luminal type $(406.4 \pm 68.3 \mathrm{ng} / \mathrm{mL})$ were significantly lower than those with triple negative type $(506.8 \pm 175.5 \mathrm{ng} / \mathrm{mL})(P<0.001)$. The mean CD44 levels of HER2-enriched type was $462.5 \pm 125.4$ $\mathrm{ng} / \mathrm{mL}$ and had no difference with those of luminal $(P$ $=0.124)$ and triple negative types $(P=0.502)$. The mean serum ALDH1A1 levels was $1.053 \pm 1.204$ $\mathrm{ng} / \mathrm{mL}$ in luminal type, $1.421 \pm 1.927 \mathrm{ng} / \mathrm{mL}$ in HER2-enriched type and $1.848 \pm 1.924 \mathrm{ng} / \mathrm{mL}$ in triple negative type, separately. There was no correlation between serum ALDH1A1 levels and molecular subtypes.

Table 2. Univariate and multivariate analysis of prognostic factors that influenced overall survival.

\begin{tabular}{|c|c|c|c|c|}
\hline & Univariate & & Multivariate & \\
\hline Characteristics & HR $(95 \% \mathrm{CI})$ & $\begin{array}{l}P \\
\text { value }\end{array}$ & $\mathrm{HR}(95 \% \mathrm{CI})$ & $\begin{array}{l}P \\
\text { value }\end{array}$ \\
\hline \multicolumn{5}{|l|}{ Age (years) } \\
\hline$>35$ & 1 & & & \\
\hline$\leq 35$ & $2.006(0.942-4.271)$ & 0.071 & & \\
\hline \multicolumn{5}{|l|}{ Tumor size $(\mathrm{cm})$} \\
\hline$\leq 2$ & 1 & & 1 & \\
\hline 2 to 5 & $2.605(1.246-5.449)$ & 0.011 & $2.091(0.984-4.443)$ & 0.055 \\
\hline$>5$ & $\begin{array}{l}4.373 \\
(1.775-10.775)\end{array}$ & 0.001 & $3.563(1.376-9.226)$ & 0.009 \\
\hline \multicolumn{5}{|c|}{ Lymph nodes status (+) } \\
\hline 0 & 1 & & 1 & \\
\hline $1-3$ & $2.983(1.502-5.923)$ & 0.002 & $2.305(1.136-4.678)$ & 0.021 \\
\hline$\geq 4$ & $\begin{array}{l}5.454 \\
(2.636-11.285)\end{array}$ & $<0.001$ & $\begin{array}{l}5.436 \\
(2.584-11.433)\end{array}$ & $<0.001$ \\
\hline \multicolumn{5}{|l|}{ ER status } \\
\hline Negative & 1 & & 1 & \\
\hline Positive & $0.459(0.266-0.792)$ & 0.005 & $0.606(0.297-1.236)$ & 0.168 \\
\hline \multicolumn{5}{|l|}{ PR status } \\
\hline Negative & 1 & & 1 & \\
\hline Positive & $0.541(0.313-0.935)$ & 0.028 & $0.817(0.403-1.656)$ & 0.574 \\
\hline \multicolumn{5}{|c|}{ HER2 $(\mathrm{IHC} / \mathrm{FISH}) \dagger$ status } \\
\hline Negative & 1 & & & \\
\hline Positive & $1.344(0.737-2.449)$ & 0.335 & & \\
\hline \multicolumn{5}{|c|}{ Serum CD44 (ng/mL) } \\
\hline$<368.3$ & 1 & & 1 & \\
\hline 368.3 to 417.4 & $0.972(0.405-2.336)$ & 0.95 & $1.089(0.447-2.652)$ & 0.851 \\
\hline 417.4 to 477.9 & $1.227(0.51-2.952)$ & 0.648 & $1.521(0.599-3.858)$ & 0.378 \\
\hline$\geq 477.9$ & $3.038(1.435-6.429)$ & 0.004 & $2.874(1.286-6.423)$ & 0.01 \\
\hline \multicolumn{5}{|c|}{$\begin{array}{l}\text { Serum ALDH1A1 } \\
(\mathrm{ng} / \mathrm{mL})\end{array}$} \\
\hline$<0.778$ & 1 & & & \\
\hline$\geq 0.778$ & $1.240(0.717-2.144)$ & 0.441 & & \\
\hline
\end{tabular}


A

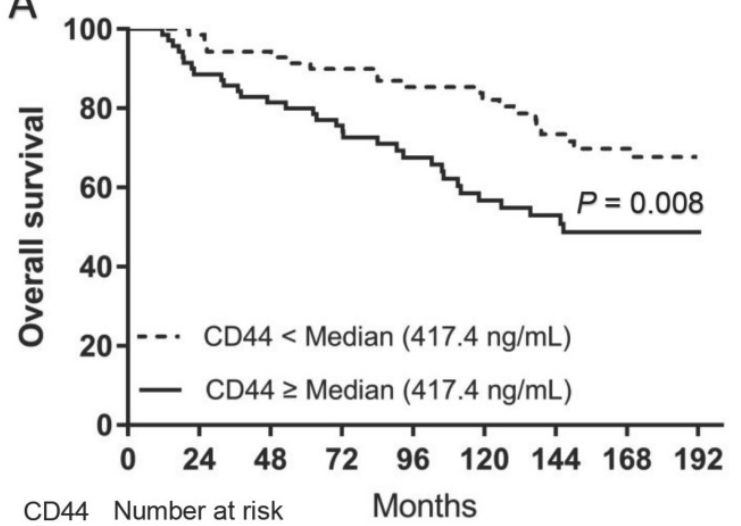

CD44 Number at risk

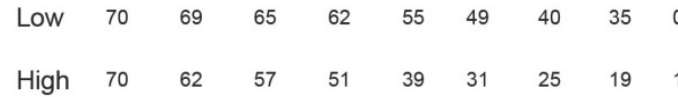

C

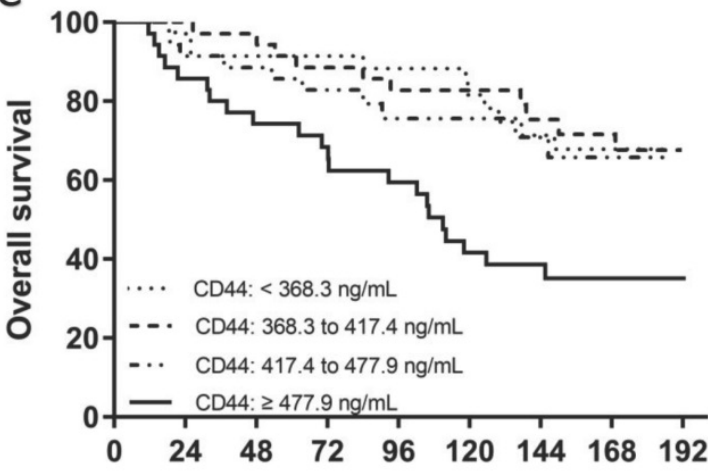

CD44 Number at risk Months

$$
\begin{array}{llllllllll}
\ldots & 35 & 34 & 31 & 31 & 28 & 24 & 20 & 17 & 0 \\
\ldots & 35 & 35 & 34 & 31 & 27 & 25 & 20 & 18 & 0 \\
-. . & 35 & 32 & 31 & 28 & 19 & 17 & 14 & 9 & 0 \\
- & 35 & 30 & 26 & 23 & 20 & 14 & 11 & 10 & 1
\end{array}
$$

Fig. 1. Kaplan-Meier survival curve for OS and PFS according to serum CD44 levels. Two subgroups were divided according to median level (A and $B$ ). Patients with high serum CD44 levels $(\geq 417.4 \mathrm{ng} / \mathrm{mL})$ had both worse OS (A) and PFS (B) than those with low serum CD44 levels $(<417.4 \mathrm{ng} / \mathrm{mL})(P=0.008$ for OS and $P=0.019$ for PFS, separately). Four subgroups were divided according to quartiles (C and D). Patients with serum CD44 levels $(\geq 477.9 \mathrm{ng} / \mathrm{mL}) \mathrm{had}$ both worse OS ([C], CD44 level $<368.3 \mathrm{ng} / \mathrm{mL}$ : $P=0.002$; CD44 level between $368.3 \mathrm{ng} / \mathrm{mL}$ and $417.4 \mathrm{ng} / \mathrm{mL}: P=0.002$; and CD44 level between $417.4 \mathrm{ng} / \mathrm{mL}$ and $477.9 \mathrm{ng} / \mathrm{mL}: P=0.015)$ and $P F S$ ([D], CD44 level $<368.3$ $\mathrm{ng} / \mathrm{mL}: P=0.016$; CD44 level between $368.3 \mathrm{ng} / \mathrm{mL}$ and $417.4 \mathrm{ng} / \mathrm{mL}: P=0.002$; and CD44 level between $417.4 \mathrm{ng} / \mathrm{mL}$ and $477.9 \mathrm{ng} / \mathrm{mL}: P=0.033$ ) than other three subgroups (OS: $P=0.008$ for OS and $P=0.019$ for PFS, separately). However, there was no difference of OS and PFS among other three subgroups $(P>0.05)$.

A

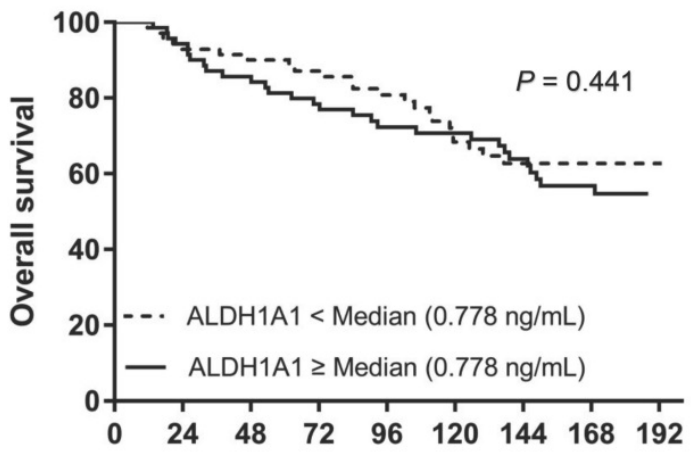

ALDH1 Number at risk Months

$\begin{array}{llllllllll}\text { Low } & 70 & 65 & 63 & 59 & 48 & 37 & 29 & 27 & 1 \\ \text { High } & 70 & 66 & 59 & 53 & 46 & 43 & 36 & 27 & 0\end{array}$

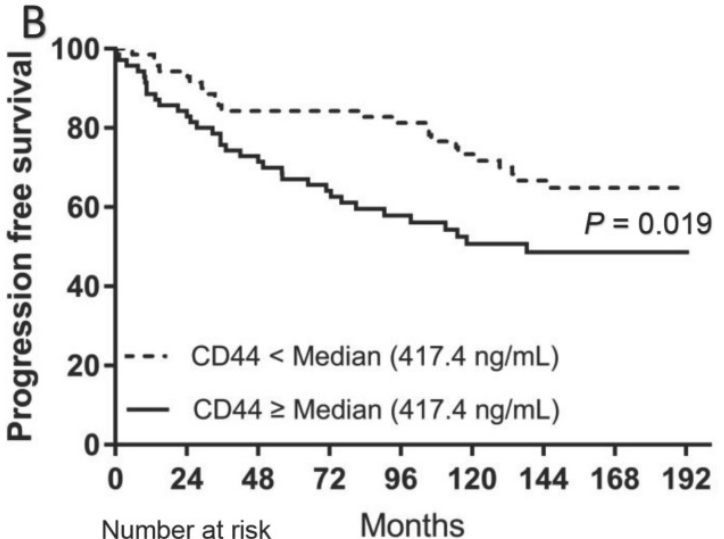

$\begin{array}{lllllllll}70 & 66 & 59 & 59 & 53 & 44 & 37 & 33 & 0\end{array}$

D

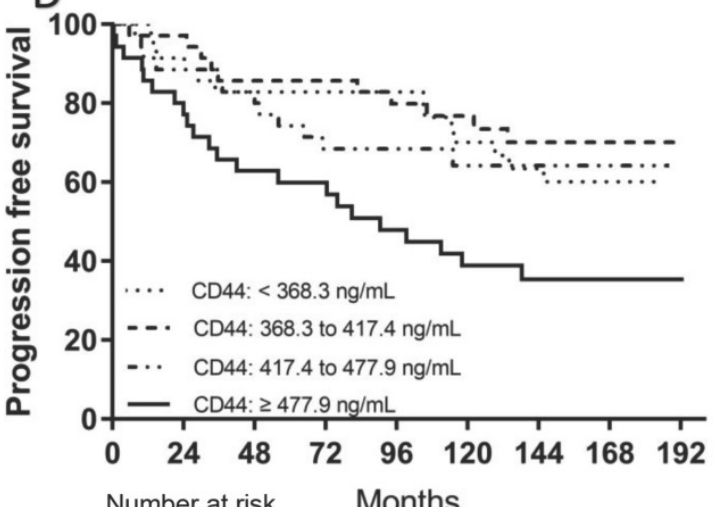

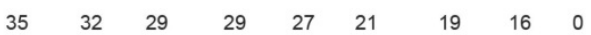

$\begin{array}{lllllllll}35 & 34 & 30 & 30 & 26 & 23 & 18 & 17 & 0\end{array}$

$\begin{array}{lllllllll}35 & 31 & 29 & 23 & 18 & 15 & 13 & 9 & 0\end{array}$

$\begin{array}{lllllllll}35 & 28 & 22 & 20 & 16 & 13 & 10 & 10 & 1\end{array}$
B

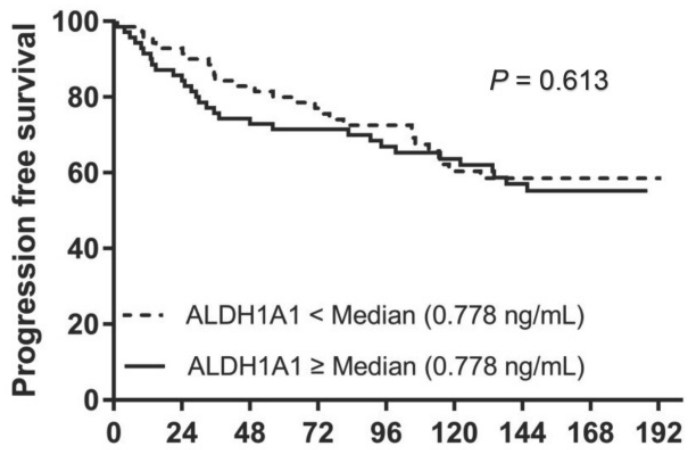

Number at risk Months

$\begin{array}{lllllllll}70 & 65 & 58 & 52 & 44 & 33 & 28 & 26 & 1 \\ 70 & 60 & 52 & 50 & 43 & 39 & 32 & 26 & 0\end{array}$

Fig. 2. Kaplan-Meier survival curve for OS and PFS according to serum ALDHIAl levels. Both OS (A) and PFS (B) were not found with significant differences between patients with high serum ALDHIAl levels and those with low serum ALDH1A1 levels $(P=0.441$ for OS and $P=0.613$ for $P F S$, separately). 
Table 3. Univariate and multivariate analysis of prognostic factors that influenced progression free survival.

\begin{tabular}{|c|c|c|c|c|}
\hline & Univariate & & Multivariate & \\
\hline Characteristics & HR $(95 \% \mathrm{CI})$ & $P$ value & $\mathrm{HR}(95 \% \mathrm{CI})$ & $P$ value \\
\hline \multicolumn{5}{|l|}{ Age (years) } \\
\hline$\leq 35$ & 1 & & & \\
\hline$>35$ & $0.536(0.256-1.067)$ & 0.075 & & \\
\hline \multicolumn{5}{|l|}{ Tumor size $(\mathrm{cm})$} \\
\hline$\leq 2$ & 1 & & 1 & \\
\hline 2 to 5 & 2.039 (1.055-3.939) & 0.034 & $1.717(0.874-3.373)$ & 0.117 \\
\hline$>5$ & $4.081(1.797-9.264)$ & 0.001 & 3.631 (1.521-8.672 & 0.004 \\
\hline \multicolumn{5}{|c|}{ Lymph nodes status } \\
\hline 0 & 1 & & 1 & \\
\hline $1-3$ & $2.654(1.329-4.943)$ & 0.005 & $1.982(1.007-3.898)$ & 0.048 \\
\hline$\geq 4$ & $6.076(3.086-11.96)$ & $<0.001$ & $6.747(3.36-13.549)$ & $<0.001$ \\
\hline \multicolumn{5}{|l|}{ ER status } \\
\hline Negative & 1 & & 1 & \\
\hline Positive & $0.453(0.269-0.764)$ & 0.003 & $0.644(0.33-1.255)$ & 0.196 \\
\hline \multicolumn{5}{|l|}{ PR status } \\
\hline Negative & 1 & & 1 & \\
\hline Positive & $0.526(0.311-0.887)$ & 0.016 & $0.735(0.38-1.422)$ & 0.361 \\
\hline \multicolumn{5}{|c|}{ HER2 $(\mathrm{IHC} / \mathrm{FISH}){ }^{\dagger}$ status } \\
\hline Negative & 1 & & & \\
\hline Positive & $1.264(0.709-2.253)$ & 0.427 & & \\
\hline \multicolumn{5}{|c|}{ Serum CD44 (ng/mL) } \\
\hline$<368.3$ & 1 & & 1 & \\
\hline 368.3 to 417.4 & $0.747(0.327-1.703)$ & 0.488 & $0.811(0.352-1.87)$ & 0.623 \\
\hline 417.4 to 477.9 & $1.069(0.487-2.346)$ & 0.868 & $1.129(0.496-2.572)$ & 0.772 \\
\hline$\geq 477.9$ & $2.271(1.142-4.515)$ & 0.019 & $2.255(1.098-4.631)$ & 0.027 \\
\hline \multicolumn{5}{|c|}{ SerumALDH1A1 (ng/mL) } \\
\hline$<0.778$ & 1 & & & \\
\hline$\geq 0.778$ & $1.144(0.680-1.925)$ & 0.613 & & \\
\hline
\end{tabular}

\section{Discussion}

In this study, we selected two most widely used BCSCs markers CD44 and ALDH1A1 and measured their circulating levels in the serum of 140 primary breast cancer patients. It was found that serum CD44 was a significant predictor of OS and PFS for breast cancer. However, serum ALDH1A1 levels has no impact on either OS or PFS, though high serum ALDH1A1 levels correlated with HER2 positive status.

CD44 has been identified as a reliable marker for BCSCs and plays an important role in tumor invasion and metastasis [5]. As a cell surface adhesion molecule, CD44 is composed of an extracellular domain, a transmembrane domain, and a cytoplasmic tail [12]. Proteolytic ectodermal cleavage of the extracellular domain of CD44, also called soluble extracellular CD44 is released into circulation and can be detected in serum [19]. Previous studies found that serum CD44 is highly prevalent in various malignancies, including lung cancers, gastric cancers, colon cancers, ovarian carcinomas and cervical cancer [20-24]. Elevated serum CD44 was also proved to be associated with poor outcome and disease progression in hematological malignancies, such as non-Hodgkin's lymphoma and B-cell lymphoma [25,
26]. In our study, we detected that the amount of serum CD44 is relatively abundant, ranged from 220.8 $\mathrm{ng} / \mathrm{mL}$ to $1216.7 \mathrm{ng} / \mathrm{mL}$ with the median concentration of $417.4 \mathrm{ng} / \mathrm{mL}$, indicating that serum CD44 might be a possible serum biomarker in breast cancer. We observed that high serum CD44 levels were correlated with postmenopausal status, ER negativity, PR negativity and adjuvant chemotherapy. However, there have been studies showed that upregulations of serum CD44 were associated with larger tumor size, lymph node or distant metastasis and higher stage in breast cancer patients [27, 28], that is different from ours. This may be caused by that the patients in our study were diagnosed of breast cancer with stage I-III but other studies included stage IV cases. To be mentioned, it was found that the mean serum CD44 levels of breast cancer patients with luminal subtype were significantly lower than those with triple negative subtype. Though no previous studies evaluated the relationship between serum CD44 levels and breast cancer molecular subtypes, data showed that more BCSCs existed in triple negative breast cancer than in Luminal breast cancer [29], which may well explain our findings. Patients in the high serum CD44 group had a significantly shorter OS than those in the low CD44 group, indicating that serum CD44 may be a prognostic factor for breast cancer. Baek JM et al. studied serum CD44 in HER2-positive breast cancer and demonstrated that serum CD44 was a significant predictor of OS for HER2-positive but not for all breast cancer [19]. Variance of population and sample size may contribute to the divergence.

In 2007 Ginestier C et al. found that ALDH1 is a better marker of BCSCs and a predictor of poor clinical outcome. Fewer $\mathrm{ALDH}^{+}$tumor cells can produce tumors in immunodeficient mice than CD44 ${ }^{+}$ and CD24- tumor cells [7]. In this study, the median serum ALDH1A1 levels were $0.778 \mathrm{ng} / \mathrm{mL}$, ranged from 0 and $8.085 \mathrm{ng} / \mathrm{mL}$. The concentrations were relatively low and almost $0 \mathrm{ng} / \mathrm{mL}$ in 20 patients of all 140 cases. This might be attributed to the distribution of ALDH1A1 in cell [30]. ALDH1 mainly expressed in cytoplasm and mitochondria, indicating that it may not easily pass through the membrane and be released into circulation. To be noticed, we observed that patients with high ALDH1A1 levels had a higher frequency of positive HER2 status than those who with low ALDH1A1 levels. However, there was no significant difference between patients with high serum ALDH1A1 levels and low in either OS or PFS, indicating that there may be some underlying relationships between ALDH1A1 and HER2, but serum ALDH1A1 may not be an appropriate candidate for predicting prognosis of breast cancer. 
There are some limitations in our study. First, this is a retrospective study and the serum samples were collected years before. Though stored properly, the active substance in serum may be degraded at varying degrees. Second, the sample size is relatively small, which may lead to bias.

To our knowledge, there has not been any study exploring the serum levels of BCSCs markers CD44 and ALDH1A1 at the same time in breast cancer patients. The results from our study showed that patients with high levels of CD44 have shorter PFS and OS. Furthermore, univariate and multivariate survival analysis demonstrated that serum CD44 is an independent factor for prognosis in breast cancer. However, serum ALDH1A1 has no impact on either PFS or OS and is not an appropriate candidate to predict prognosis for breast cancer.

\section{Abbreviations}

ALDH: aldehyde dehydrogenase

BCSCs: breast cancer stem cells

CI: confidence interval

CTCs: circulating tumor cells

ER: estrogen receptor

HR: hazard ratio

OS: overall survival

PFS: Progression free survival

\section{Acknowledgements} study.

We thank all the patients who participate in this

\section{Funding support}

This work was supported by the Medical Scientific Technological Research Funding of Guangdong Province, China [grant number A2015280].

\section{PR, progesterone receptorAuthors' contributions}

Xiaoming Xie, Weidong Wei, Yanan Kong, Hailing Tang and Jiali $\mathrm{Wu}$ conceived and designed the study. Yanan Kong, Hailing Tang, Jiali Wu, Ning Lyu, Xinhua Xie, Lu Yang and Xing Li collected the data. Yanan Kong, Hailing Tang, Jiali $\mathrm{Wu}$, and Ning Lyu analyzed and interpreted the data. All authors were involved in the drafting, review, and approval of the report and the decision to submit for publication.

\section{Competing Interests}

The authors have declared that no competing interest exists.

\section{References}

1. Torre LA, Bray F, Siegel RL, Ferlay J, Lortet-Tieulent J, Jemal A. Global cancer statistics, 2012. CA Cancer J Clin. 2015; 65: 87-108.
2. Page DB, Naidoo J, McArthur HL. Emerging immunotherapy strategies in breast cancer. Immunotherapy. 2014; 6: 195-209.

3. Liu S, Cong Y, Wang D, Sun Y, Deng L, Liu Y, et al. Breast cancer stem cells transition between epithelial and mesenchymal states reflective of their normal counterparts. Stem Cell Reports. 2014; 2: 78-91.

4. Smalley M, Piggott L, Clarkson R. Breast cancer stem cells: obstacles to therapy. Cancer Lett. 2013; 338: 57-62.

5. Al-Hajj M, Wicha MS, Benito-Hernandez A, Morrison SJ, Clarke MF. Prospective identification of tumorigenic breast cancer cells. Proc Natl Acad Sci U S A. 2003; 100: 3983-8.

6. Al-Haji M, Clarke MF. Self-renewal and solid tumor stem cells. Oncogene. 2004; 23: 7274-82.

7. Ginestier C, Hur MH, Charafe-Jauffret E, Monville F, Dutcher J, Brown M, et al. ALDH1 is a marker of normal and malignant human mammary stem cells and a predictor of poor clinical outcome. Cell Stem Cell. 2007; 1: 555-67.

8. Yang L, Tang H, Kong Y, Xie X, Chen J, Song C, et al. LGR5 Promotes Breast Cancer Progression and Maintains Stem-Like Cells Through Activation of Wnt/beta-Catenin Signaling. Stem Cells. 2015; 33: 2913-24.

9. Cristofanilli M, Budd GT, Ellis MJ, Stopeck A, Matera J, Miller MC, et al. Circulating tumor cells, disease progression, and survival in metastatic breast cancer. N Engl J Med. 2004; 351: 781-91.

10. Riethdorf S, Fritsche H, Muller V, Rau T, Schindlbeck C, Rack B, et al. Detection of circulating tumor cells in peripheral blood of patients with metastatic breast cancer: a validation study of the CellSearch system. Clin Cancer Res. 2007; 13: 920-8.

11. Ignatiadis M, Lee M, Jeffrey SS. Circulating Tumor Cells and Circulating Tumor DNA: Challenges and Opportunities on the Path to Clinical Utility. Clin Cancer Res. 2015; 21: 4786-800.

12. Fillmore C, Kuperwasser C. Human breast cancer stem cell markers CD44 and CD24: enriching for cells with functional properties in mice or in man? Breast Cancer Res. 2007; 9: 303.

13. Charafe-Jauffret E, Ginestier C, Iovino F, Wicinski J, Cervera N, Finetti P, et al. Breast cancer cell lines contain functional cancer stem cells with metastatic capacity and a distinct molecular signature. Cancer Res. 2009; 69: 1302-13.

14. Atkinson RL, Yang WT, Rosen DG, Landis MD, Wong H, Lewis MT, et al. Cancer stem cell markers are enriched in normal tissue adjacent to triple negative breast cancer and inversely correlated with DNA repair deficiency. Breast Cancer Res. 2013; 15: R77.

15. Ali HR, Dawson SJ, Blows FM, Provenzano E, Pharoah PD, Caldas C. Cancer stem cell markers in breast cancer: pathological, clinical and prognostic significance. Breast Cancer Res. 2011; 13: R118.

16. Soady KJ, Kendrick H, Gao O, Tutt A, Zvelebil M, Ordonez LD, et al. Mouse mammary stem cells express prognostic markers for triple-negative breast cancer. Breast Cancer Res. 2015; 17: 31

17. Wei W, Tweardy DJ, Zhang M, Zhang X, Landua J, Petrovic I, et al. STAT3 signaling is activated preferentially in tumor-initiating cells in claudin-low models of human breast cancer. Stem Cells. 2014; 32: 2571-82.

18. Neumeister $\mathrm{V}$, Agarwal $\mathrm{S}$, Bordeaux J, Camp RL, Rimm DL. In situ identification of putative cancer stem cells by multiplexing ALDH1, CD44, and cytokeratin identifies breast cancer patients with poor prognosis. Am J Pathol. 2010; 176: 2131-8.

19. Baek JM, Jin Q, Ensor J, Boulbes DR, Esteva FJ. Serum CD44 levels and overall survival in patients with HER2-positive breast cancer. Breast Cancer Res Treat. 2011; 130: 1029-36.

20. Yoo CH, Noh SH. The Serum Assay of Soluble CD44 Standard, CD44 Variant 5, and CD44 Variant 6 in Patients with Gastric Cancer. Cancer Res Treat. 2003; 35: 3-8.

21. Shinohara S, Hanagiri T, Taira A, Takenaka M, Oka S, Chikaishi Y, et al. Immunohistochemical Expression and Serum Levels of CD44 as Prognostic Indicators in Patients with Non-Small Cell Lung Cancer. Oncology. 2016; 90: 327-38.

22. Dasari S, Rajendra W, Valluru L. Evaluation of soluble CD44 protein marker to distinguish the premalignant and malignant carcinoma cases in cervical cancer patients. Med Oncol. 2014; 31: 139.

23. Muinao T, Deka Boruah HP, Pal M. Diagnostic and Prognostic Biomarkers in ovarian cancer and the potential roles of cancer stem cells - An updated review. Exp Cell Res. 2018; 362: 1-10.

24. Senbanjo LT, Chellaiah MA. CD44: A Multifunctional Cell Surface Adhesion Receptor Is a Regulator of Progression and Metastasis of Cancer Cells. Front Cell Dev Biol. 2017; 5: 18

25. Shah N, Cabanillas F, McIntyre B, Feng L, McLaughlin P, Rodriguez MA, et al. Prognostic value of serum CD44, intercellular adhesion molecule-1 and vascular cell adhesion molecule-1 levels in patients with indolent non-Hodgkin lymphomas. Leuk Lymphoma. 2012; 53: 50-6.

26. Molica S, Vitelli G, Levato D, Giannarelli D, Gandolfo GM. Elevated serum levels of soluble CD44 can identify a subgroup of patients with early B-cell chronic lymphocytic leukemia who are at high risk of disease progression. Cancer. 2001; 92: 713-9.

27. Sheen-Chen SM, Chen WJ, Eng HL, Sheen CC, Chou FF, Cheng YF. Evaluation of the prognostic value of serum soluble CD 44 in patients with breast cancer. Cancer Invest. 1999; 17: 581-5.

28. Mayer S, zur Hausen A, Watermann DO, Stamm S, Jager M, Gitsch G, et al. Increased soluble CD44 concentrations are associated with larger tumor size and lymph node metastasis in breast cancer patients. J Cancer Res Clin Oncol. 2008; 134: 1229-35. 
29. Ricardo S, Vieira AF, Gerhard R, Leitao D, Pinto R, Cameselle-Teijeiro JF, et al. Breast cancer stem cell markers CD44, CD24 and ALDH1: expression distribution within intrinsic molecular subtype. J Clin Pathol. 2011; 64: 937-46.

30. Sophos NA, Vasiliou V. Aldehyde dehydrogenase gene superfamily: the 2002 update. Chem Biol Interact. 2003; 143-144: 5-22. 